\section{Kelsey Sitar*}

\section{"Environmental Policy \& Natural Resources in Federalist Canada"}

\begin{abstract}
*Kelsey Sitar is currently in her fourth year at St. Francis Xavier University. Her areas of study are Political Science and Canadian Studies.
\end{abstract}

There are very few issues arising in Canadian politics that are not, in some way, affected by our federal system of government. The British North America Act of 1867 outlined how Canada would operate. Obviously oversimplified, this document stated that the two recognized levels of government, federal and provincial, would divide powers in most issues, with only some shared or concurrent by both federal and provincial governments. In this sense, Canada was already quite distinctive, because most of the other federal countries tended to share powers with only a few designated to fall under only one government's jurisdiction.

However, in 1867, there was no way the founding fathers could predict all issues that Canada would face in the future; neither could they predict the long-term implications of the power divisions they created. One power given to the provinces that was deemed of little value at the moment was control and ownership over natural resources. Largely stemming from provincial jurisdiction over property and civil rights, provinces were also given the sole responsibility of exploration for, and conservation of non-renewable resources (Fournier et al 2). Also stemming from the property and civil rights jurisdiction, and largely tied to development of resources, was the eventual provincial majority control over environmental regulations (Simeon 10).

Environmental degradation and the need for protection are examples of issues the founding fathers could not have possibly predicted. Due to their failure to be designated in the British North America Act, both levels of government have been able to sidestep these issues when it is convenient, make decisions when it is politically valuable, and battle over jurisdiction when it is appropriate. Again, our approach to federalism greatly affects the viability of and approaches to this policy sector. Particularly interesting is environmental policy development, or lack thereof, in relation to natural gas exploration and development.

\section{Natural Gas \& Federalsim in Canada}

Natural resource jurisdiction has become a particularly hot issue within the Canadian context, and the battles surrounding the royalty-rich oil and gas sector is no exception. Different resources raise different questions, comments, and concerns by different governments and groups; so, the focus on one particular resource sector is almost essential to avoid overly confusing the issues.

Canadian provinces have the undeniable jurisdiction over natural gas that is discovered, harvested, transported, and processed within their territorial borders - offshore and territorial disputes. However, any mode of transportation that crosses provincial or international boundaries then becomes wards of the federal government (Fournier et al 2). While provinces have maintained these rights since Confederation, territories have witnessed an expansion of rights in regards to oil and natural gas. The Yukon Territory received the basic equivalent of provincial rights over its natural gas reserves in 1998, provided that these resources are found in onshore deposits (Fournier et al 3). In the Northwest Territories, many First Nations groups with hydrocarbon deposits located on reserve lands have received mineral right transfers in recent years (Fournier et al 4). However, the development and processing of these resources do not exist in a vacuum. All of these actions have shown to be direct causes of extreme forms of environmental degradation. It is within this linked areaoil, natural gas, and the environment - that jurisdictional boundaries have become blurred and disputed.

\section{Environmental Policy in Canada}

As previously outlined, the founding fathers of Confederation could never have imagined how parasitical the human race would become on its global host. Envisioning the need for environmental regulation was not anywhere remotely near the constitutional drawing board. Since the rise of these issues within the national psyche, there have been continual debates between nongovernmental persons, as well as intergovernmental participants and analysts, as to where jurisdictional lines should be drawn within this key policy sector.

The Canadian system inherently leans towards a divided rather than shared model of federalism (Cameron 10). Historically, when cases have been brought to the JCPC or the Supreme Court of Canada, the tendency has been to favour provinces in questions of jurisdiction (Cameron 10). One would expect this trend to continue regarding environmental policy issues. In fact, many policy analysts have predicted greater provincial power due to the inherent tendency of Canadian federalism to make provinces more autonomous, powerful, and influential than their comparable counterparts in other federations (Rabe et al 2).

There are two basic approaches that could be taken to environmental policy within a federal system. The first would involve the implication of national standards, a process supported by environmentalists, especially when compared to its alternative. National standards would conceivably lead to a "race to the middle," by which 
negotiations would result in a middle-ground compromise, and force compliance of all provincial governments (Litfin 7). The alternate approach would be to allow each province to have sole jurisdiction over environmental policy, a fearful possibility for the environmentally concerned. This arrangement would inevitably lead toward a "race to the bottom," with provinces attempting to outbid oil and gas producing companies by offering lower taxes, and lower environmental standards, thereby lowering overall operation costs. In fact, it was neither of these concrete options that the Canadian government chose when attempting to settle jurisdictional questions surrounding environmental policy.

\section{Canada-Wide Accord on Ewvironmental Harmonization, 1998}

In 1998, the federal government and nine provinces, excluding Quebec, agreed to and signed the Canada-Wide Accord on Environmental Harmonization. In simple terms, this document served as a formal shift of many environmental powers to the provinces (Cameron 15). In designing a one-window system-all services to be provided by only one level of government - the overall result should have become a more efficient, cost effective, environmental policy sector in Canada. Many argue this was not the case.

There exist aspects that were, for whatever reason, still overlooked when debating and defining the terms of the Harmonization Accord. While designation reduced the intergovernmental conflict, it also neglected to consider the inherent inequitable abilities between the larger/ wealthier, and smaller/poorer provinces. The weaker infrastructure of many provinces has made them less able to provide comprehensive environmental services that were delegated to them through the Accord (Cameron 15). Another key issue, central to the discussion of environmental policy as it relates to the example of the oil and natural gas sector, is the failure to define the enforcement potential of the federal government regarding international treaties.

\section{Treaty Signing \& Implementation}

While the ability of the federal government to negotiate, sign, and ratify international agreements has remained undisputed since 1876, the ability of these administrations to enforce regulations on areas of provincial jurisdiction remains a hotly debated issue in Canadian circles.

Perhaps the most recent example of this disagreement can be found within the Kyoto Accord discussions and signature. Revolving around the rising international concern surrounding global warming, the Kyoto Accord was initiated as an international agreement to reduce the production of greenhouse gasses known to contribute to this debilitating phenomenon. Canada was a strong supporter during the negotiations as a federal government, but at home tempers were flaring.
Alberta, the producer of over eighty percent of Canada's oil and natural gas (Oil \& Gas Journal), lead by its Progressive Conservative premier, Ralph Klein, was livid at the negotiations that would so adversely affect the economy of his province. Although the right of the federal government to sign treaties was not under question, Klein and others took issue with Prime Minister Jean Chretien's ability to enforce treaty terms within areas of provincial jurisdiction. Development and conservation of natural resources was unquestionably a provincial power. Could Ottawa impede on this jurisdictional designation with the terms of a ratified international treaty? Officials from both Alberta and Saskatchewan hinted publicly that this would not be the case and that they would not adhere to the terms of Kyoto if Chretien chose to become a signatory (Litfin 6).

With economies so dependent on oil and gas production, it is no wonder why these governments became heated over the terms of Kyoto. At the time of signing, Jean Chretien had no clear plan as to how the Accord would be implemented at home, and there was no provincial consultation. With eighty-one percent of oil and gas reserves in Alberta being owned by the provincial government, royalties paid on these reserves make up a majority of the province's successful economy (Fournier et al 2). Not only is it tied to the development of natural gas as a resource, it is also closely tied economically to trade with the United States, and the presence of transnational corporations within the exploration and development sectors of oil and gas (Litfin 6). With the United States freeriding on Kyoto - not becoming a signatory - the hypothetical economic disadvantages that may face Alberta in the implementation of Kyoto would also affect this integral fiscal relationship.

\section{Dangers of Jurisdictional Ambiguity}

The danger of jurisdictional ambiguity, especially in the minds of many environmentalists, is very real. With further delegation of powers to the provinces, many environmentalists fear that jurisdiction could inevitably be used as a cop-out by the federal administration (Paehlke 10). Many would rather face the infighting and inefficiency that may be bred by concurrent powers, than the 'automatic out' potentially created for the federal government by assigning environmental policy powers to the provinces. A frightening, potential foreshadowing of this federal disengagement can be seen in simple statistics. The federal government of Canada reduced its spending on environmental issues by thirty-two percent between 1995 and 1998 (Paehlke 5). This reduction occurred even before jurisdictional boundaries were somewhat clarified by the Harmonization Accord.

As it has been illustrated by the Kyoto Accord, this jurisdictional uncertainty reverberates out towards Canada's role in international environmental policy. While the federal government can unquestionably sign international agreements, it has even internally admitted that it cannot 
necessarily guarantee provincial compliance with any or all aspects (Litfin 5).

\section{Potential for Positive Change}

The area of environmental policy, especially with relation to the oil and gas sector, is not an abominable black hole of despair and disengagement. Although environmental groups and political analysts have pointed to many discouraging factors, there have been some potentially positive steps made within other federal and non-federal institutions.

One example of this is activist decisions made by the Supreme Court. Repeatedly, decisions made have been positive responses to the use of the criminal-law power in regards to environmental issues (Cameron 12). Although this does not directly expand the role and power of the federal government in regards to environmental policy per se, it does leave room for potential enforcement and prosecution of persons who do not adhere to specific standards under the criminal code - over which the federal government has unchallengeable, unilateral jurisdiction.

Another example is the initiative taken by several provincial governments to address and respond to environmental issues independent of the federal government. An illustration of this is found in the Conference of New England Governors and Eastern Canadian Premiers, which has held annual meetings since 1973 (Dennison 10). Together, these politicians have crafted many firsts in environmental international agreements for Canada, including the first agreements regarding acid rain, limitation of greenhouse gases, and limitation of mercury emissions, respectfully.

Another reassurance put forth by some analysts is that, as globalization continues, the role of the federal government will become increasingly minimal. The term "globalization," coined by Courchene, refers to the theory that the capacity and importance of national governments will deteriorate as the affects of globalization increase (Simeon 6). Subscribers to this point of view would assure those worried by increased provincial jurisdictional powers that this would have occurred eventually anyhow, and that the role of the federal government is not as significant as we may now think.

\section{Summary}

Many regard Canada as a unique case of federalism. While most federal countries utilize a system of many concurrent powers, Canada's interpretations juxtaposes this, with most powers being unilateral, and usually falling to the provinces rather than the federal government. However, despite a carefully laid out plan for power distribution, there was no way our founding fathers could have predicted every potential issue to ever face the Canadian nation.

Although natural resources, grouped under the property and civil rights clause of the British North America Act, are unchallenged as a provincial power, the resulting environmental consequences from harvesting and utilizing these are far less clear. Specifically, the production and consumption of hydrocarbon fuels have created many issues in the recent past, and raised an equal number of questions regarding whose responsibility it is to protect the environment.

One approach to the global threat of hydrocarbon use has been the drafting and ratification of international treaties, such as the Kyoto Accord. While the Canadian federal system undeniably gives the power to sign international agreements to the federal government, the right to enforce the conditions outlined in these documents is far less clear. Especially sketchy is the right of the federal government to enforce signed, international agreements, which set limits impinging on areas of provincial jurisdiction. Although Canada has taken distinct steps towards clarifying and designating environmental powers, exemplified within the Harmonization Accord, it has conveniently avoided volatile areas concerning enforcement of treaties.

However, there are signs of hope for those concerned with the government of Canada's ability to create and enforce environmental policy. Recent court decisions have supported the federal government's use of the criminal-law power, perhaps leading towards an ultimate authority on environmental questions. Other hopeful events include the increase in international, state/provincial-level organizations to negotiate treaties. Finally, others comfort the concerned with their theoretical decline in importance of the national governments, leading us to believe that the distribution of power to provincial governments may have indeed been an inevitable occurrence.

Overall, the role of federalism in environmental policy, especially relating to natural resources, is evolving at an essentially rapid rate. With more and more international agreements surfacing on the use of hydrocarbons, the global affects of individual nation's actions, and the growing public concern surrounding environmental issues, it seems virtually inevitable that the federal system of Canada must evolve and adapt to include and effectively deal with these pressing issues. 0

\section{References}

Cameron, David. "Intergovernmental Relations in Canada," as published on Forum of Federations. http://www.forumfed.org. Last accessed November 25, 2003.

Dennison, Don. "Intergovernmental Relations in Canada," as published on Forum of Federations, http://www.forumfed.org. Last accessed November 25, 2003.

Fournier, Dan \& Mungo Hardwicke-Brown \& Craig Spurn. "Canada's Energy Sector," International Financial Law Review, London, 2002, p. 69.

Litfin, Karen T. "Advocacy Coalitions Along the DomesticForeign Frontier: Globalization and Canadian Climate Change Policy," Policy Studies Journal, Vol. 28, Iss. 1, p. 236. 
Oil \& Gas Journal. "Alberta Producers, Government pleased with RIK arrangement,” Oil \& Gas Journal, Vol. 96, Iss. 25, pg. 25.

Paehlke, Robert. "Environmentalism in One Country: Canadian Environmental Policy in an Era of Globalization," Policy Studies Journal, Vol. 28, Iss. 1, p. 160.
Rabe, Barry G. \& William R. Lowry. "Comparative Analysis of Canadian and American Environmental Policy: An Introduction to the Symposium," Policy Studies Journal, Vol. 27, Iss. 2, p. 263.

Simeon, Richard. "Making Federalism Work: Intergovernmental Coordination and Institutional Capacity," as published on Forum of Federations. http://www.forumfed.org. Last accessed on November 25, 2003. 